\title{
Novel devices for implant-based breast reconstruction: is the use of meshes to support the lower pole justified in terms of benefits? A review of the evidence
}

\author{
Lorna Jane Cook and Tibor Kovacs \\ Guy's and St Thomas' NHS Trust, London SE11 4TX, UK \\ Correspondence to: Tibor Kovacs. Email: tibor.kovacs@gstt.nhs.uk
}

\begin{abstract}
The use of novel devices such as acellular dermal matrices (ADMs) to support the lower pole in implant-based breast reconstructions (IBBRs) has been described as one of the most important advances in breast reconstructive surgery following mastectomy. However, the majority of outcomes studies focus primarily on providing evidence for the rates of short-term complications associated with their use, as opposed to their reported benefits. Given the high costs associated with using ADMs, together with an increasing number of alternative, cheaper synthetic products entering the market, it is important to clarify whether their use is actually justified and whether the alternative products offer equivalent or superior outcomes. The purpose of this article is to present a comprehensive and updated review of the evidence for the benefits of using different products for lower pole support (LPS) in IBBR compared to reconstructions without. A secondary aim was to determine if there is any evidence to support the use of one product over another.
\end{abstract}

Keywords: breast reconstruction, implants, acellular dermal matrices, complications and benefits

Published: 10/01/2018

Received: 29/03/2017

ecancer 2018, 12:796 https://doi.org/10.3332/ecancer.2018.796

Copyright: (c) the authors; licensee ecancermedicalscience. This is an Open Access article distributed under the terms of the Creative Commons Attribution License (http://creativecommons.org/licenses/by/3.0), which permits unrestricted use, distribution, and reproduction in any medium, provided the original work is properly cited. 


\section{Introduction}

Increased survival from breast cancer as a result of advances in both diagnosis and treatment has meant that 'quality-of-life' measures are becoming an increasingly important indicator of treatment success, as opposed to mortality rates alone [1]. Since breast reconstruction after mastectomy is associated with significant improvements in both psychosocial outcomes and body image, such surgery has become a key consideration in the multidisciplinary management of breast cancer [2]. Consequently, novel techniques and devices in the field of breast reconstruction surgery have been developed with the aim of improving outcomes and meeting patient expectations.

Implant-based breast reconstruction (IBBR) is the most commonly used technique and offers a safe, simple approach to reconstructive surgery, without the need for a long operation or use of donor site tissue [3, 4] Traditionally, a two-stage 'sub-muscular' technique has been used, in which, following mastectomy, a 'pocket' is developed under the chest wall musculature into which an expander-type implant is placed and the skin flaps are closed over it. The expander implant is then sequentially inflated with saline over a period of weeks until the desired size is reached, after which it is exchanged for a definitive or 'fixed volume' implant as a second procedure [2]. The nature of the muscular pocket can either be 'total' (in which the pectoralis major, serratus anterior and rectus abdominalis muscle or fascia are elevated and sutured together anterior to the implant); or 'partial', where only the upper pole is covered by the pectoralis major [5-7].

Both of these traditional sub-muscular techniques are, however, associated with disadvantages. With partial sub-muscular coverage, the inferior pole is covered only by the skin of the mastectomy flap, predisposing to implant extrusion or exposure, particularly in the presence of necrosis or infection [7,8]. While total sub-muscular coverage of the implant protects it from potential exposure, it requires extensive muscular dissection and may cause pain during the expansion phase. Both techniques can result in lack of control over the position of the inframammary fold (IMF), in a flat unnatural look or make it difficult to achieve a natural looking ptosis [9, 10].

\section{The ‘lower pole support' (LPS) technique}

In an attempt to overcome some of these limitations, the traditional sub-muscular technique has been modified in recent years through the additional use of novel materials as adjuncts. Whilst still placing the implant beneath the pectoralis muscle, the 'LPS' technique additionally employs the use of a biological or synthetic mesh to cover the lower pole of the implant by suturing it to the IMF and the lower border of the pectoralis major muscle $[9,11]$. This technique has the advantage not only of providing support to the lower pole of the implant by acting as a sling but also increases the overall size of the pocket such that, in selected cases, there is the option to proceed directly to a one-stage procedure using a fixed volume implant [12]. When first introduced, the mesh used for this technique was the acellular dermal matrix (ADM) 'Alloderm', which is derived from human cadaveric dermis [13, 14]. Since then, multiple alternative products have entered the market - an overview of which is provided below.

\section{Materials currently used for the 'LPS' technique}

\section{Acellular matrices}

ADMs are sterile, acellular, biological pieces of material derived from human or animal skin, in which the dermis is stripped of the cellular components, leaving a structurally intact and biochemically inert, extracellular matrix [15]. While the human skin-derived ADM, 'Alloderm' was the first ADM to be described in the literature, multiple ADMs derived from both allogenic and xenograft (porcine and bovine) donor sources are now in use. These products differ in their processing and as a result have differences in handling, incorporation, shelf life and cost. In addition to ADMs, de-cellularised tissue derived from other tissue sources, such as the pericardium and peritoneum, have also been developed which have similar properties $[16,17]$ (Table 1). 
Table 1. ADMs and synthetic meshes commonly used in IBBR.

\begin{tabular}{|c|c|c|c|}
\hline Category & Product name & Source/material & Details \\
\hline \multirow{10}{*}{ ADM } & Alloderm & \multirow{7}{*}{ Human dermis } & Freeze-dried, aseptic, requires refrigeration and rehydration prior to use \\
\hline & Alloderm RTU & & Sterile, pre-hydrated, two-minute soak only \\
\hline & $\begin{array}{l}\text { Alloderm contour } \\
\text { fenestrated }\end{array}$ & & $\begin{array}{l}\text { Sterile, pre-hydrated, crescent shape to ease use and fenestrated to allow } \\
\text { passage of any periprosthetic fluid }\end{array}$ \\
\hline & FlexHD & & Pre-hydrated \\
\hline & DermaMatrix & & Freeze-dried aseptic, requires rehydration \\
\hline & CGDerm & & Freeze dried, requires 20 minutes' rehydration \\
\hline & CGCryoDerm & & Frozen but not dried, only required three minutes' soak in saline \\
\hline & Strattice & Porcine dermis & Sterile \\
\hline & Protexa & Porcine dermis & Sterile \\
\hline & Surgimend & Bovine dermis & Sterile \\
\hline Other biologics & $\begin{array}{l}\text { Veritas } \\
\text { Meso BioMatrix }\end{array}$ & $\begin{array}{l}\text { Bovine pericardium } \\
\text { Porcine preitoneum }\end{array}$ & $\begin{array}{l}\text { Fenestrated mesh made of decellularised pericardium } \\
\text { Derived from porcine mesothelium }\end{array}$ \\
\hline \multirow{3}{*}{ Synthetic mesh } & TiLOOP bra & Titanised polypropelene & Non-absorbable mesh \\
\hline & TIGR mesh & Absorbable mesh & Macropourous mesh made of two types of co-polymer fibres \\
\hline & Vicryl Mesh & Absorbable mesh & Dissolves rather than integrates into tissue \\
\hline Other materials & SERI silk & Multifilament silk mesh & Behaves like an ADM in vivo allowing in-growth of new tissue \\
\hline
\end{tabular}

\section{Alternative meshes}

The widespread acceptance of the technique together with concerns regarding the high cost of ADMs has led to the development of alternative synthetic mesh types for use in IBBR [18].

\section{Ti-LOOP Bra}

TiLOOP Bra (pfm medical titanium, Nuremberg, Germany) is a non-absorbable, titanium coated polypropylene mesh (TCPM), which has been approved for use in breast reconstruction since 2008. It has a knitted monofilament structure and comes available in three different bra-like sizes. Production involves introducing titanium in gaseous form so that it reaches all parts of the mesh, forming covalent bonds with the plastic surface [19].

\section{SeriSilk}

SERIsilk is a silk-derived biological scaffold in which silk filaments are combined by helical twisting to form a multifilament fibre which is purified and then assembled into a three-dimensional scaffold. Laboratory studies have suggested that it behaves more like an ADM in vivo than a Vicryl mesh, in which it is not just absorbed but accompanied by new tissue generation such that the strength and load bearing properties are transferred to the newly ingrown tissue [20].

\section{TIGR® Matrix Surgical Mesh}

TIGR® Matrix is an absorbable, macroporous mesh knotted from two different degradable fibres - a fast degrading fibre and a slow degrading fibre. The fast degrading fibre is a co-polymer between glycolide and trimethylene carbonate and the slow degrading fibre is a copolymer between lactide and trimethylene. The idea is that the fast degrading fibre gives extra support during the wound healing phase but is totally resorbed after four months, while the slow absorbing fibre keeps its mechanics up to 6-9 months and is not completely reabsorbed until three years later [21]. 


\section{Vicryl mesh}

Vicryl mesh is comprised of polyglactin 910 and is cheap, ready to use and widely available. It also exhibits minimal inflammatory reaction, is non-allergenic and resistant to bacteria biofilm formation. One of the greatest benefits of using Vicryl meshes as an alternative to ADMs is the cost difference, estimated at being two-thirds less [22].

\section{Benefits of using a mesh as an adjunct in IBBR}

There are several reported benefits associated with the use of an ADM in IBBR, which include improved cosmesis, better patient satisfaction, less post-operative pain, less capsular contracture and improved cost-effectiveness (mainly as a result of facilitating one-stage procedures and reducing time to completion of fill in two-stage procedures). Some of these benefits are believed to also be associated with the use of the synthetic meshes but with much less associated cost. Whilst there have been multiple literature and systematic reviews exploring outcomes of ADM use in IBBR, their focus has been predominantly on complication profiles and process evaluation rather than evaluating the available evidence for the benefits of their use [23-27].

\section{Objectives}

The purpose of this article is to present a comprehensive and updated review of the literature on the evidence for the benefits of using a mesh in IBBR, compared to reconstructions without a mesh. A secondary aim was to identify any studies which compared the outcomes of using an ADM with an alternative synthetic mesh.

\section{Methods}

\section{Search strategy}

We searched the Ovid SP versions of EMBASE and MEDLINE (last updated 01/7/2017) for relevant articles using the search strategy detailed in Table 2.

\section{Inclusion criteria}

(a) Studies published from 2007 onwards

(b) Studies reporting on outcomes following the use of a mesh for LPS in IBBR after mastectomy (to include ADMs, all other biologics and synthetic meshes)

(c) Comparative studies only either comparing outcomes between mesh and non-mesh reconstructions or between reconstructions using different mesh types

(d) Clinical outcome studies reporting on at least one of:

1. cosmetic outcomes (assessed via an objective method);

2. capsular contracture rates (assessed using the Baker scale)

3. post-operative pain;

4. patient-reported outcomes (using a validated method);

5. cost-effectiveness (based on individual patient data not literature review/theoretical). 
Table 2. Search strategy.

\begin{tabular}{|c|l|}
\hline No & \multicolumn{1}{|c|}{ Term } \\
\hline 1 & Breast/ \\
\hline 2 & Breast.mp \\
\hline 3 & 1 or 2 \\
\hline 4 & Biocompatible materials/ \\
\hline 5 & ADM.mp \\
\hline 6 & Acellular derm ${ }^{*} . m p$ \\
\hline 7 & strattice.mp \\
\hline 8 & Surgimend.mp \\
\hline 9 & Dermamatrix.mp \\
\hline 10 & Alloderm.mp \\
\hline 11 & Allomax.mp \\
\hline 12 & FlexHD.mp \\
\hline 13 & TIGR mesh.mp \\
\hline 14 & TiLOOP.mp \\
\hline 15 & Veritas.mp \\
\hline 16 & Seri.mp \\
\hline 17 & $\begin{array}{l}4 \text { or } 5 \text { or } 6 \text { or } 7 \text { or } 8 \text { or } 9 \text { or } 10 \text { or } \\
11 \text { or } 12 \text { or } 13 \text { or } 14 \text { or } 15 \text { or } 16\end{array}$ \\
\hline 18 & $\begin{array}{l}\text { Reconstructive surgical proce- } \\
\text { dures/ }\end{array}$ \\
\hline 19 & 'Prostheses and implants'/ \\
\hline 20 & Breast implants/ \\
\hline 21 & Tissue expansion devices/ \\
\hline 22 & Implant*.mp \\
\hline 23 & Expand*.mp \\
\hline 24 & Prosthe ${ }^{*} . m p$ \\
\hline 25 & Surgery, plastic/ \\
\hline 26 & $\begin{array}{l}18 \text { or } 19 \text { or } 20 \text { or } 21 \text { or } 22 \text { or } 23 \\
\text { or } 24 \text { or } 25\end{array}$ \\
\hline 27 & 3 and 17 and 26 \\
\hline 29 & Limit 27 to Humans, English \\
Language \\
\hline
\end{tabular}

\section{Exclusion criteria}

(a) Single cohort case series without a comparator

(b) Comparative studies where comparator cohort does not meet the inclusion criteria above

(c) Non-clinical, animal- or lab-based studies

(d) Studies reporting solely on cosmetic or revision procedures

(e) Non-English language articles

(f) Conference abstracts or abstracts without full text available. 


\section{Data extraction}

Data extracted from the included papers were author, journal, year of publication, outcome measure(s) described, study type, participants per cohort compared, mesh types used, methodology used, outcomes per cohort and follow-up periods.

\section{Results and Discussion}

We identified a total of 12 unique articles that met the inclusion criteria. Of these 10/12 compared ADM-based reconstructions to non-mesh reconstructions, 1/12 compared synthetic mesh (TiLOOP) reconstructions to non-mesh reconstructions and 1/12 compared ADM reconstructions to TiLOOP reconstructions (Figure 1). There were two RCTs with the remainder being non-randomised comparative retrospective cohort studies. A narrative description of the included studies grouped per mesh type and outcome measure reported is given below.

\section{Evidence for the benefits of using ADMs versus non ADM reconstructions}

\section{Evidence for improved cosmesis}

We identified four articles meeting the inclusion criteria which compared the cosmetic outcomes between ADM and non-ADM reconstructions [28-31]. All the four studies used panel assessment of standardised clinical post-operative photographs and a validated scoring system, although the specific methodology differed between studies (Table 3). The ADM type used was specified in two of the studies as being Alloderm [30] and both Alloderm and Surgimend [28], and was unspecified in the remaining two.

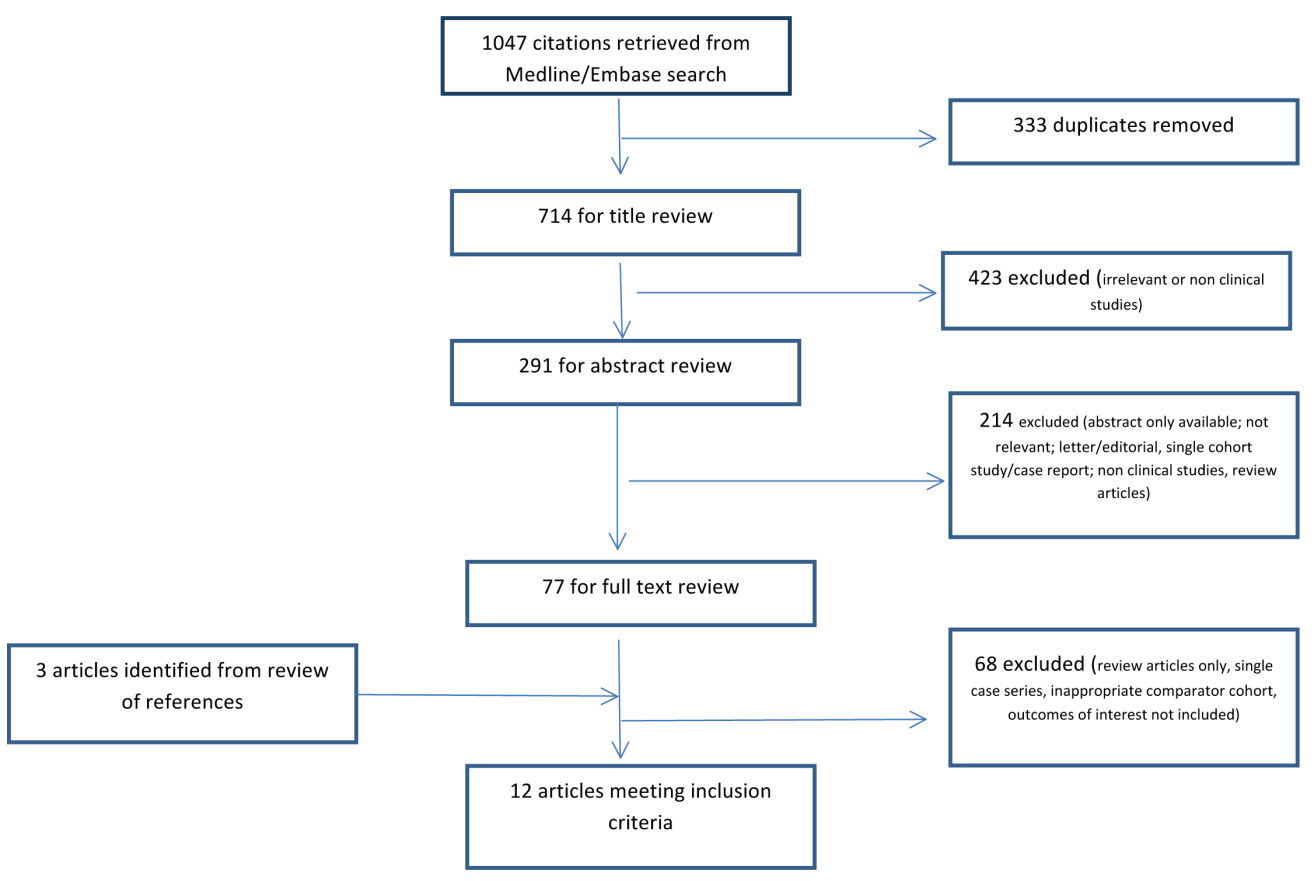

Figure 1. PRISMA diagram. 
Table 3. Cosmetic outcome studies - ADM versus non-ADM cohort.

\begin{tabular}{|c|c|c|c|c|c|c|}
\hline Author & $\begin{array}{l}\text { Cohorts } \\
\text { compared }\end{array}$ & $\begin{array}{c}\text { Variables } \\
\text { compared } \\
\text { at baseline }\end{array}$ & $\begin{array}{c}\text { Assessors/method } \\
\text { used }\end{array}$ & $\begin{array}{l}\text { Follow-up period/ } \\
\text { time of assessment }\end{array}$ & $\begin{array}{l}\text { Method of } \\
\text { evaluation }\end{array}$ & Results \\
\hline $\begin{array}{l}\text { Ibrahim } \\
\text { et al [28], } \\
2015\end{array}$ & $\begin{array}{l}\text { ADM (Alloderm or } \\
\begin{array}{l}\text { Surgimend) } n=18 \\
\text { patients }\end{array} \\
\begin{array}{l}\text { Non-ADM } n=20 \\
\text { patients }\end{array}\end{array}$ & Yes NSD & $\begin{array}{l}\text { Panel assessment of } \\
\text { pre-/post-operative } \\
\text { photographs by five } \\
\text { plastic surgeons not } \\
\text { directly involved in } \\
\text { care and blinded }\end{array}$ & $\begin{array}{l}\text { Six months to seven } \\
\text { years ( } 1.7 \text { years) } \\
\text { Not compared } \\
\text { between groups }\end{array}$ & $\begin{array}{l}\text { Scored using } \\
\text { validated subscales } \\
\text { for volume; con- } \\
\text { tour; placement of } \\
\text { implant; scars; lower } \\
\text { pole projection; IMF } \\
\text { definition }\end{array}$ & $\begin{array}{l}\text { ADM cohort scored } \\
\text { statistically signifi- } \\
\text { cantly higher in terms } \\
\text { of overall cosmetic } \\
\text { outcome and for sub- } \\
\text { scales for contour and } \\
\text { implant placement }\end{array}$ \\
\hline $\begin{array}{l}\text { Forsberg } \\
\text { et al [29], } \\
2014\end{array}$ & $\begin{array}{l}\text { ADM (type not } \\
\text { specified) } n=58 \\
\text { reconstructions } \\
\text { Non-ADM } n=125 \\
\text { reconstructions }\end{array}$ & $\begin{array}{l}\text { Yes - } \\
\text { significantly } \\
\text { more delayed } \\
\text { reconstructions } \\
\text { in non-ADM } \\
\text { cohort }\end{array}$ & $\begin{array}{l}\text { Panel assessment of } \\
\text { post-operative photo- } \\
\text { graphs; } 18 \text { blinded } \\
\text { assessors (six plastic } \\
\text { surgeons; six trainees; } \\
\text { six medical students) }\end{array}$ & $\begin{array}{l}\text { ADM: } 25 \text { months } \\
\text { Non-ADM: } 34 \text { months } \\
\text { Significant difference } \\
p=0.005\end{array}$ & $\begin{array}{l}\text { Scored using vali- } \\
\text { dated subscales for } \\
\text { contour; symmetry } \\
\text { of shape; symmetry } \\
\text { of size; position and } \\
\text { overall outcome }\end{array}$ & $\begin{array}{l}\text { ADM cohort received } \\
\text { higher scores for all } \\
\text { parameters in each } \\
\text { group of assessors. } \\
\text { Difference reached } \\
\text { significance for } \\
\text { majority }\end{array}$ \\
\hline $\begin{array}{l}\text { Nguyen } \\
\text { et al [31], } \\
2012\end{array}$ & $\begin{array}{l}\text { ADM (type not } \\
\text { specified) } n=53 \\
\text { patients } \\
\text { Non-ADM n = 58 }\end{array}$ & $\begin{array}{l}\text { Yes - sig- } \\
\text { nificantly higher } \\
\text { BMI in ADM } \\
\text { cohort }\end{array}$ & $\begin{array}{l}\text { Panel assessment of } \\
\text { post-operative photo- } \\
\text { graphs; three plastic } \\
\text { surgeons not involved } \\
\text { in care; blinded }\end{array}$ & $\begin{array}{l}\text { Not specified, } \\
\text { although photo- } \\
\text { graphs taken at least } \\
90 \text { days following } \\
\text { second-stage } \\
\text { procedure }\end{array}$ & $\begin{array}{l}\text { Scored using } \\
\text { validated subscales } \\
\text { for volume; con- } \\
\text { tour; placement of } \\
\text { implant; scars; lower } \\
\text { pole projection; IMF } \\
\text { definition }\end{array}$ & $\begin{array}{l}\text { ADM cohort scored } \\
\text { statistically signifi- } \\
\text { cantly higher in terms } \\
\text { of overall cosmetic } \\
\text { outcome and for sub- } \\
\text { scales for volume, IMF } \\
\text { definition and implant } \\
\text { placement }\end{array}$ \\
\hline $\begin{array}{l}\text { Vardanian } \\
\text { et al [30], } \\
2011\end{array}$ & $\begin{array}{l}\text { ADM (Alloderm) } \\
n=208 \text { recon- } \\
\text { structions } \\
\text { Non-ADM - partial } \\
(n=119) \text { and } \\
\text { total }(n=10) \\
\text { sub-muscular }\end{array}$ & Yes NSD & $\begin{array}{l}\text { Panel assessment of } \\
\text { post-operative photo- } \\
\text { graphs; four blinded } \\
\text { assessors - surgeon, } \\
\text { secretary and two medi- } \\
\text { cal students }\end{array}$ & $\begin{array}{l}\text { Not stated - all } \\
\text { post-implant } \\
\text { exchange }\end{array}$ & $\begin{array}{l}\text { Four-point Harris } \\
\text { scale for overall } \\
\text { aesthetic outcome } \\
\text { and IMF placement } \\
\text { (1 - poor; } 2 \text { - fair; } \\
3 \text { - good; } 4 \text { - } \\
\text { excellent) }\end{array}$ & $\begin{array}{l}\text { Score for both overall } \\
\text { aesthetic outcome } \\
\text { and IMF placement } \\
\text { significantly higher in } \\
\text { ADM cohort }\end{array}$ \\
\hline
\end{tabular}

NSD: no significant difference.

All the studies reported that patients in the ADM cohorts had significantly higher overall cosmetic scores compared to the non-ADM cohorts. However, the follow-up period was either not stated per cohort or was significantly different. Given that satisfaction with cosmetic outcomes has been shown to decline over time [32], this may have had a differential effect on the outcome. Furthermore, the studies were not randomised and there were significant differences between the cohorts at baseline in two of the studies (Table 3).

\section{Evidence for improved Patient-Reported Outcome Measures (PROMs)}

Two articles compared PROMs between ADM and non-ADM reconstructions using a validated method (Table 4) [33, 34]. McCathy et al [33] randomised patients undergoing two-stage IBBR following mastectomy into receiving Alloderm or not. By using the 'chest and upper body morbidity' domains of the BREASTQ questionnaire as well as a visual analogue scale for postoperative pain, they found no significant difference between the two cohorts either immediately post-operatively or during the expansion phase. However, as described in further detail in the following section, there may have been limitations in the study design/methodology that impacted on these results. 
The second study by Hanna et al [34] used the 'Breast Evaluation Questionnaire' to assess whether there was a difference in PROMs between 31 patients who underwent IBBR with Alloderm and 44 patients with total sub-muscular coverage. No significant difference between the two cohorts was demonstrated in all areas of the questionnaire. The only factors identified which influenced the scores were whether reconstructions were bilateral or unilateral and whether patients underwent treatment with radiotherapy or not. In addition to this being a small study, however, the response rate was low overall at $45.3 \%$ and there was a difference of over 10 months in length of followup between the two cohorts. Furthermore, this was a non-randomised study and there was no stated reason as to why patients were allocated into one cohort or the other.

\section{Evidence for improved pain outcomes}

McCarthy et al [33], in addition to using the BREASTQ and visual analogue scale for pain described above, objectively evaluated pain outcomes using 24-hour post-operative narcotic use (reported as oral codeine equivalent). They reported no significant difference between the two cohorts in terms of narcotic requirements $(p=0.38)$. However, the size of the ADM used $(4 \times 16 \mathrm{~cm})$ was significantly smaller than that generally used in practice, such that the full effect of increased pocket size on reducing pain, particularly during the expansion phase, may not have been realised as a result (Table 5).

The second study by Seth et al [35] was a non-randomised retrospective cohort study which compared outcomes between patients having two-stage reconstruction with and without Alloderm. Patients were additionally stratified according to whether or not the patients received post-operative radiotherapy. Post-operative pain was assessed according to whether it had been specifically documented in patient notes on at least one occasion during the period of follow-up. There was no significant difference in reported pain between the cohorts overall. However, when patients were additionally stratified into those who did or did not have post-mastectomy radiotherapy, the non-ADM cohort reported a significantly higher prevalence of pain in the radiotherapy group, whereas no difference was seen in the ADM cohort. Although the sample size is small, the authors suggest this difference may be a consequence of the protective effect of the ADM in reducing capsular contracture.

\section{Evidence for reduced levels of capsular contracture}

Despite encouraging evidence from single cohort case series which report very low rates of capsular contracture when compared to preexisting data from non-ADM cohorts [36, 37], only two comparative studies were identified that met the inclusion criteria [29, 30] (Table 6). Vardanian et al [30] performed a retrospective comparison of the outcomes of two-stage reconstruction with or without the use of Alloderm ADM in 203 patients and reported a significantly lower rate of capsular contracture (Baker grade III or IV) in the ADM cohort at a mean follow-up of 29 months $(3.8 \%$ versus $19.4 \% \mathrm{p}<0.001)$. A second study by Forsberg et al [29] also found capsular contracture was significantly lower, although the ADM type used was not specified $(8.1 \%$ versus $23.5 \% p=0.048)$.

Both of these comparative studies have potential sources of bias, however, which limit how far their results can be accepted. Both the studies were retrospective and based on case note review alone as opposed to prospective and standardised evaluation of Baker grade of contracture. Furthermore, capsular contracture rate is known to increase over time and both the studies had short median follow-up periods, which was significantly less in the ADM cohort in the study of Forsberg et al [29] and was not reported on a per cohort basis in the study of Vardanian et al [30].

\section{Evidence for cost-benefits}

Three non-randomised comparative cohort studies addressed the question of a cost-benefit when comparing ADM reconstructions with non-ADM reconstructions. Three additional articles were identified but were excluded as they used literature searches/systematic reviews to pool data on outcomes from case series rather than using patient level data [38-40]. All three included studies used different methodologies (Table 7). 
Table 4. Studies comparing PROMs between ADM versus non-ADM reconstructions.

\begin{tabular}{|c|c|c|c|c|c|c|c|}
\hline Reference & $\begin{array}{l}\text { Methods/materials } \\
\text { compared }\end{array}$ & $\begin{array}{l}\text { Selection } \\
\text { into cohort }\end{array}$ & $\begin{array}{l}\text { Validated PROMS } \\
\text { instrument } \\
\text { used/subscales }\end{array}$ & $\begin{array}{l}\text { Response } \\
\text { rate }\end{array}$ & Follow-up period & Results & Comments \\
\hline $\begin{array}{l}\text { McCarthy } \\
\text { et al [33], } \\
2012\end{array}$ & $\begin{array}{l}\text { ADM: Alloderm } \\
\mathrm{n}=36 \text { patients } \\
\text { Non-ADM: } \mathrm{n}=33 \\
\text { patients }\end{array}$ & Randomised & $\begin{array}{l}\text { The Physical Well- } \\
\text { being: chest and } \\
\text { upper body domain of } \\
\text { the BREASTQ pre-/ } \\
\text { post-reconstruction } \\
\text { module } \\
\text { Visual analogue scale } \\
\text { Prospective }\end{array}$ & $100 \%$ & $\begin{array}{l}\text { Immediately } \\
\text { post-operatively; } \\
\text { following the } \\
\text { 1st-3rd post-op } \\
\text { expansions and } \\
\text { immediately } \\
\text { prior to implant } \\
\text { exchange }\end{array}$ & $\begin{array}{l}\text { No significant } \\
\text { difference in } \\
\text { scores for either } \\
\text { BREASTQ or } \\
\text { VAS at all stages } \\
\text { of reconstruction } \\
\text { measured }\end{array}$ & $\begin{array}{l}\text { Recruitment } \\
\text { stopped early } \\
\text { due to slow } \\
\text { accrual. Smaller } \\
\text { sized mesh used } \\
\text { than is generally } \\
\text { used in current } \\
\text { practice }\end{array}$ \\
\hline $\begin{array}{l}\text { Hanna } \\
\text { et al [34], } \\
2013\end{array}$ & $\begin{array}{l}\text { ADM: Alloderm } \\
n=31 \text { patients } \\
\text { Non-ADM } n=44\end{array}$ & $\begin{array}{l}\text { Method } \\
\text { not stated, } \\
\text { consecutive } \\
\text { patients }\end{array}$ & $\begin{array}{l}\text { Breast Evaluation } \\
\text { Questionnaire (phone } \\
\text { assessment), retro- } \\
\text { spective }\end{array}$ & $\begin{array}{l}45.3 \% \\
\text { Rate between } \\
\text { groups not } \\
\text { compared }\end{array}$ & $\begin{array}{l}\text { ADM } 10.2+/-7.7 \\
\mathrm{~m} \\
\text { TSR } 20.7+/-11 \mathrm{~m} \\
\text { No } \mathrm{p} \text { value stated }\end{array}$ & $\begin{array}{l}\text { No significant dif- } \\
\text { ference between } \\
\text { the two cohorts in } \\
\text { terms of respons- } \\
\text { es to all questions. }\end{array}$ & $\begin{array}{l}\text { Low response } \\
\text { rate and small } \\
\text { patient population }\end{array}$ \\
\hline
\end{tabular}

Table 5. Studies comparing pain outcomes between cohorts.

\begin{tabular}{|c|c|c|c|c|c|c|}
\hline Reference & $\begin{array}{c}\text { Methods/materials } \\
\text { compared }\end{array}$ & $\begin{array}{l}\text { Selection } \\
\text { into cohort }\end{array}$ & $\begin{array}{c}\text { Method of pain } \\
\text { assessment }\end{array}$ & Results & $\begin{array}{c}\text { Follow-up period } \\
\text { (timing of assessment) }\end{array}$ & Conclusions \\
\hline $\begin{array}{l}\text { McCarthy } \\
\text { et al [33], } \\
2012\end{array}$ & $\begin{array}{l}\text { ADM: Alloderm } \\
n=36 \text { patients } \\
\text { Non-ADM: } \\
n=33 \text { patients }\end{array}$ & Randomised & $\begin{array}{l}\text { PROMS (see } \\
\text { Table 2) } \\
\text { 24-hour } \\
\text { post-operative } \\
\text { narcotic use } \\
\text { (reported as } \\
\text { oral codeine } \\
\text { equivalent) }\end{array}$ & $\begin{array}{l}\text { No significant difference in } \\
\text { scores for either BREASTQ } \\
\text { or VAS at all stages of } \\
\text { reconstruction measured. } \\
\text { No significant difference } \\
\text { in post-operative narcotic } \\
\text { requirements } p=0.38\end{array}$ & $\begin{array}{l}\text { Immediately post-opera- } \\
\text { tively, following the } 1 \text { st- } \\
\text { 3rd post-op expansions } \\
\text { and immediately prior to } \\
\text { implant exchange. } \\
24 \text { hours post-operatively }\end{array}$ & $\begin{array}{l}\text { No evidence for } \\
\text { reduction in post- } \\
\text { operative pain with } \\
\text { use of an ADM either } \\
\text { immediately or in the } \\
\text { expansion phase } \\
\text { of two-stage breast } \\
\text { reconstruction }\end{array}$ \\
\hline $\begin{array}{l}\text { Seth et al } \\
\text { [35], } 2012\end{array}$ & $\begin{array}{l}\text { ADM: Alloderm/Flex } \\
\text { HD } \\
\mathrm{N}=199 \text { breasts } / 137 \\
\text { patients } \\
\text { No ADM } 393 \\
\text { breasts/280 patients }\end{array}$ & Not stated & $\begin{array}{l}\text { Recorded if } \\
\text { documented } \\
\text { by surgeon } \\
\text { following at least } \\
\text { one subjective } \\
\text { patient complaint }\end{array}$ & $\begin{array}{l}\text { ADM: Pain documented } \\
\text { for five patients }(2.5 \%) \text { and } \\
\text { for ten non-ADM patients } \\
(2.5 \%) \\
p=0.60 \text {. } \\
\text { No difference in the ADM } \\
\text { cohort when stratified } \\
\text { according to radiotherapy } \\
\text { exposure; significantly } \\
\text { more patients reported pain } \\
\text { if exposed to radiotherapy } \\
\text { in the non-ADM cohort }\end{array}$ & $\begin{array}{l}\text { ADM } 23.2+/-8.9 \\
\text { months }(3-45) \\
\text { Non ADM24.4 +/- } 12.7 \\
(4-49) p=0.23\end{array}$ & $\begin{array}{l}\text { Authors suggest } \\
\text { that this differential } \\
\text { effect of radiotherapy } \\
\text { on pain may be a } \\
\text { consequence of the } \\
\text { protective effect of the } \\
\text { ADM due to reduced } \\
\text { capsular contracture }\end{array}$ \\
\hline
\end{tabular}


Table 6. Comparative studies evaluating capsular contracture (cc) rates (ADM versus Non-ADM).

\begin{tabular}{|c|c|c|c|c|c|}
\hline Reference & Groups compared & Variables & Method of assessment & Follow-up period & Results \\
\hline $\begin{array}{l}\text { Vardanian } \\
\text { et al [30], } \\
2011\end{array}$ & $\begin{array}{l}\text { ADM (Alloderm) } \\
n=208 \\
\text { Non-ADM - partial } \\
(n=119) \text { and total } \\
(n=10) \text { sub-muscular }\end{array}$ & $\begin{array}{l}\text { No significant difference } \\
\text { (NSD) between cohorts } \\
\text { in terms of age, BMI, } \\
\text { smoking and indication } \\
\text { for reconstruction }\end{array}$ & $\begin{array}{l}\text { Retrospective chart } \\
\text { review of recorded Baker } \\
\text { score. Considered signifi- } \\
\text { cant if Baker III or IV }\end{array}$ & $\begin{array}{l}\text { Median } 29 \text { months } \\
\text { post-implant exchange } \\
\text { for both cohorts - not } \\
\text { compared. Range not } \\
\text { reported }\end{array}$ & $\begin{array}{l}\text { Overall cc rates: ADM } 3.8 \% \text {; } \\
\text { non-ADM } 19.4 \% \text { p }<0.001 \text {. } \\
\text { On multivariate analysis } \\
\text { ADM use associated with } \\
\text { significantly lower cc rates } \\
\text { (OR } 0.18 ; 95 \% \text { Cl } 0.08-0.43 \text { ) }\end{array}$ \\
\hline $\begin{array}{l}\text { Forsberg } \\
\text { et al [29], } \\
2014\end{array}$ & $\begin{array}{l}\text { ADM (type not speci- } \\
\text { fied) } n=58 \\
\text { Non-ADM } n=125\end{array}$ & $\begin{array}{l}\text { NSD between cohorts in } \\
\text { terms of age, BMI, smok- } \\
\text { ing, diabetes, adjuvant } \\
\text { therapy, implant type } \\
\text { (saline/silicone) or size. } \\
\text { Significant difference in } \\
\text { the number of immediate } \\
\text { reconstructions (higher in } \\
\text { ADM cohort) and length } \\
\text { of follow-up period }\end{array}$ & $\begin{array}{l}\text { Retrospective chart } \\
\text { review of recorded Baker } \\
\text { score. Considered signifi- } \\
\text { cant if Baker III or IV }\end{array}$ & $\begin{array}{l}\text { ADM } 24.6 \text { months } \\
\text { Non-ADM } 33.8 \text { months } \\
p=0.005\end{array}$ & $\begin{array}{l}\text { Significant difference in } \\
\text { cc rates: } \\
\text { ADM: } 8.1 \% \\
\text { Non-ADM } 23.5 \% \\
\text { P }=0.048\end{array}$ \\
\hline
\end{tabular}

Table 7. Studies comparing cost-effectiveness (ADM versus Non-ADM).

\begin{tabular}{|c|c|c|c|c|c|}
\hline Reference & Study type & $\begin{array}{l}\text { Reconstructions } \\
\text { compared }\end{array}$ & Method & Factors included & Results \\
\hline $\begin{array}{l}\text { Johnson } \\
\text { et al [41], } \\
2013\end{array}$ & $\begin{array}{l}\text { Single-centre } \\
\text { cohort, } \\
\text { retrospective }\end{array}$ & $\begin{array}{l}\text { Strattice: bilateral } \\
(n=13), \text { unilateral } \\
(n=11) \\
\text { TE/l: bilateral } n=12 \\
\text { unilateral } n=10 \\
\text { LD }+ \text { implant } n=10\end{array}$ & $\begin{array}{l}\text { Use of National } \\
\text { Tariffs (NHS England } \\
\text { 2011-2012) as a proxy } \\
\text { for hospital costs plus } \\
\text { acquisition costs for } \\
\text { Strattice }\end{array}$ & $\begin{array}{l}\text { Cost of index operation, } \\
\text { consumables in addition } \\
\text { to those accounted for } \\
\text { in-tariff payment, admis- } \\
\text { sions and attendances } \\
\text { and complications }\end{array}$ & $\begin{array}{l}\text { For unilateral cases, Strattice is less costlier } \\
\text { than TE/I (£3685 vs. £4985) and LD-based } \\
\text { reconstructions ( } £ 3685 \text { vs. } £ 6321) \\
\text { For bilateral cases, Strattice is costlier than } \\
\text { TE/I due to anomaly in reimbursement } \\
\text { system where bilateral mastectomy does } \\
\text { not attract any higher reimbursement than } \\
\text { unilateral }\end{array}$ \\
\hline $\begin{array}{l}\text { Kilchenmann } \\
\text { et al [42], } \\
2014\end{array}$ & $\begin{array}{l}\text { Single-centre } \\
\text { cohort, } \\
\text { retrospective }\end{array}$ & $\begin{array}{l}\text { Unilateral recon- } \\
\text { structions only } \\
\text { Strattice one-stage } \\
n=25 \\
\text { TE// } n=27 \\
\text { LD+ implant } n=32 \\
\text { LD/TE } n=17\end{array}$ & $\begin{array}{l}\text { Use of resources } \\
\text { utilised rather than } \\
\text { costs incurred }\end{array}$ & $\begin{array}{l}\text { Cost of initial operation, } \\
\text { additional hospitalisations } \\
\text { and operative proce- } \\
\text { dures; outpatient appoint- } \\
\text { ments, seroma aspiration, } \\
\text { complication rates }\end{array}$ & $\begin{array}{l}\text { Unilateral single-stage ADM reconstructions } \\
\text { were associated with fewer resources utilised } \\
\text { compared to TE/I and LD/TE/I in both com- } \\
\text { plicated and non-complicated cases over a } \\
24-m \text { period. LD + mplantl and ADM cohorts } \\
\text { equivalent }\end{array}$ \\
\hline $\begin{array}{l}\text { Bank et al } \\
\text { [43], } 2013\end{array}$ & $\begin{array}{l}\text { Single- } \\
\text { centre, retro- } \\
\text { spective }\end{array}$ & $\begin{array}{l}\text { Uncomplicated } \\
\text { reconstructions only } \\
\text { TE/I with ADM } \\
\text { (Strattice or Al- } \\
\text { loderm) } n=84 \\
\text { Non-ADM TE/l } n \\
=48\end{array}$ & $\begin{array}{l}\text { Number of tissue } \\
\text { expansions required to } \\
\text { meet final fill volume } \\
\text { as a proxy for number } \\
\text { of outpatient clinic } \\
\text { encounters }\end{array}$ & $\begin{array}{l}\text { Total cost of each clinic } \\
\text { encounter using expen- } \\
\text { diture data from centre } \\
\text { (faculty fees, labour fees, } \\
\text { material costs). Cost of } \\
\text { ADM }\end{array}$ & $\begin{array}{l}\text { Although fewer clinic visits are required to } \\
\text { achieve final fill volume in ADM cohort the } \\
\text { savings made did not offset the cost of using } \\
\text { an ADM. Difference of } \$ 3000 \text { remained if } \\
\text { Alloderm is used and } \$ 2500 \text { if Strattice }\end{array}$ \\
\hline
\end{tabular}


Two studies evaluated the cost of using Strattice in a single-stage procedure. Johnson et al [41] compared the costs of both unilateral and bilateral reconstructions with two-stage tissue expander/implant (TE/l) reconstructions without ADM or one-stage latissimus dorsi (LD) flap + implant reconstructions. They used NHS tariffs as a proxy for actual costs incurred together with the acquisition costs for the Strattice mesh. They reported that for unilateral reconstructions, there was a cost advantage of using Strattice compared to the other two techniques. Specifically, when compared to two-stage TE/I reconstructions, a one-stage Strattice reconstruction eliminated costs associated with outpatient visits for expansions and a second procedure for implant exchange. When compared to LD + implant reconstructions, the lack of additional donor site morbidity and outpatient visits for seroma drainage also resulted in a cost advantage.

Kilchenmann et al [42] alternatively used 'resource allocation' rather than direct costs to compare unilateral one-stage reconstructions with Strattice to two-stage TE/l reconstructions; two-stage LD-TE/I reconstructions and one-stage LD flap + implant reconstruction. In agreement with Johnson et al [41], they also demonstrated a cost advantage to the single-stage approach which offsets the additional cost of the mesh. However, when compared to the one-stage LD + implant reconstructions, they found the costs were equivalent.

Bank et al [43] used the number of expansions required to achieve final expander fill volume as a proxy for the number of outpatient clinics attended post-operatively by patients undergoing uncomplicated ADM- and non-ADM two-stage TE/I reconstructions, in order to determine whether there was a difference in direct hospital costs. Although they found ADM reconstructions had indeed reduced the number of outpatient visits and associated costs, this was insufficient to offset the elevated material costs of using an ADM.

Without a standardised means of performing a cost analysis, it is difficult to be certain from these three studies as to whether use of an ADM results in a cost advantage over other techniques. Furthermore, longer term follow-up including details of revision surgery and quality-of-life data is required in order to perform a full assessment.

\section{Evidence for the benefits of using synthetic meshes versus non-mesh reconstructions}

We identified no comparative studies reporting on the outcomes of interest for SeriSilk, TIGR matrix or Vicryl meshes in IBBR.

One retrospective, non-randomised cohort study reported on the difference in outcomes between reconstructions with or without the use of a TiLOOP bra mesh (Table 8). Dieterich et al [44] compared 42 patients with a TiLOOP mesh to 42 who underwent a non-mesh reconstruction, using the BREASTQ post-reconstruction questionnaire. Analysis of responses showed no significant differences between the groups in all of the domains of the BREASTQ. However, stepwise linear regression showed a negative association of the 'satisfaction with breasts' domain with the use of the TiLOOP bra. Reasons for this difference may have been multifactorial, however. The way in which patients were selected into the TiLOOP cohort depended on intra-operative findings such as adequacy of soft tissue coverage; comparison of the two groups at baseline showed that the patients in the TiLOOP cohort had significantly lower BMls and were significantly younger - both factors which have an impact on expectations of aesthetic outcome.

Table 8. Study comparing PROMS between synthetic mesh (TiLOOP) and non-mesh reconstruction.

\begin{tabular}{|c|c|c|c|c|c|c|c|}
\hline Reference & $\begin{array}{l}\text { Methods/ } \\
\text { materials } \\
\text { compared }\end{array}$ & $\begin{array}{l}\text { Selection into } \\
\text { cohort }\end{array}$ & $\begin{array}{c}\text { Validated PROMS } \\
\text { instrument } \\
\text { used/subscales }\end{array}$ & $\begin{array}{l}\text { Response } \\
\text { rate }\end{array}$ & $\begin{array}{l}\text { Follow-up } \\
\text { period }\end{array}$ & Results & Comments \\
\hline $\begin{array}{l}\text { Dieterich } \\
\text { et al [44], } \\
2015\end{array}$ & $\begin{array}{l}\text { TiLOOP bra } \\
n=42 \\
\text { Non-mesh- } \\
n=42 \\
\text { Retrospec- } \\
\text { tive cohort }\end{array}$ & $\begin{array}{l}\text { Specific selection } \\
\text { into TiLOOP } \\
\text { cohort was } \\
\text { based on } \\
\text { decision made } \\
\text { intra-operatively }\end{array}$ & $\begin{array}{l}\text { BREASTQ - } \\
\text { post-reconstruction } \\
\text { module (all sub- } \\
\text { scales) - postal } \\
\text { questionnaire, } \\
\text { retrospective }\end{array}$ & $\begin{array}{l}67.7 \% \\
\text { NSD between } \\
\text { two groups } \\
p=0.117\end{array}$ & $\begin{array}{l}\text { TiLOOP } 18 \mathrm{~m} \\
(1-40) \\
\text { No mesh } 17.5 \mathrm{~m} \\
(1-83) \\
P=0.827\end{array}$ & $\begin{array}{l}\text { No significant differences } \\
\text { between the groups in all } \\
\text { of the domains. However, } \\
\text { stepwise linear regres- } \\
\text { sion showed a negative } \\
\text { association with "satisfac- } \\
\text { tion with breasts" scores } \\
\text { in the TiLOOP cohort }\end{array}$ & $\begin{array}{l}\text { Surgeon selection } \\
\text { into cohort and } \\
\text { significant differ- } \\
\text { ences between } \\
\text { two groups in } \\
\text { terms of BMI } \\
\text { and age }\end{array}$ \\
\hline
\end{tabular}


Capsular contracture rates were additionally compared between the two cohorts with $7 / 42$ in the non-TiLOOP group and 2/42 in the TiLOOP, developing a Baker III/IV contracture during the period of follow-up $(p=0.052)$. Cosmesis, post-operative pain and costs were not compared between the two cohorts.

\section{Studies comparing outcomes of reconstructions using ADMs versus synthetic meshes}

A single study was identified which compared outcomes (complications, cosmesis and PROMs) between synthetic mesh and ADM reconstructions [45]. Gschwantler et al [45] performed a prospective, randomised multicentre pilot study in which patients undergoing immediate breast reconstruction were allocated to receiving TiLOOP or a porcine ADM (Protexa). Patients in the ADM cohort differed significantly from the TiLOOP cohort at baseline in terms of exposure to radiotherapy and also in terms of rates of reconstructive failure (protexa $\mathrm{n}=7$ $30.4 \%$; TiLOOP $n=27.7 \%$ ).

Cosmetic outcomes were again scored using standardised post-operative photographs at six months using the four point Harris scale, by four surgeons and two external experts. They reported that cosmetic scores were significantly higher in the TiLOOP cohort. However, the ADM cohort had a significantly higher proportion of reconstructive failures, and when these cases were removed from the analysis there was no longer any significant differences found in terms of cosmesis.

Patient-reported outcomes were assessed using the EORTC QLQ C30 and BR23 questionnaires. Significantly lower scores were reported in the ADM cohort at the first post-operative visit for arm pain $(p=0.039)$ and fatigue $(p=0.03)$ and at six months for effect on family life $(p=0.021)$ and sexual interest $(p=0.039)$

Given the small numbers of patients compared, and the unusually high rate of reconstructive failure in the ADM cohort, it is difficult to draw any clear conclusions from this study.

\section{Conclusions}

Despite the popularity of using meshes as adjuncts to support the lower pole in implant-based reconstruction, this review has demonstrated a significant paucity of evidence to support the reported benefits of their use. Where there is evidence available, this is primarily for the use of ADMs rather than the newer synthetic meshes and is mainly derived from retrospective cohort studies. The need to demonstrate equivalent or superior outcomes with the use of synthetic meshes compared to ADMs is an important consideration, given that they are much less expensive to produce. Furthermore, without high-quality comparative data it is impossible for surgeons to know which mesh they should use in order to give the greatest benefit to their patients.

Previous literature reviews have focused on the complication and safety profiles of the meshes used in breast reconstruction as the primary outcome measures of interest [46-50]. Given that the primary purpose of breast reconstruction surgery is to improve psychosocial functioning and body image, it is perhaps equally important that outcomes such as cosmesis and patient satisfaction are also included as a means of evaluating the success of the technique [51]. One of the problems with this, however, is that there is as yet no agreed method by which cosmesis, PROMs and cost-benefit should be assessed objectively. Current methods used to evaluate cosmesis, as reported in this review, which involve a panel review of post-operative photographs are associated with a degree of subjectivity and inter-assessor variability [52].

The majority of the evidence base for use of meshes in implant-based reconstruction is composed of either single-cohort case series or retrospective cohort studies [53]. Ideally, well-designed prospective cohort studies or RCTs with sufficient periods of follow-up should be carried out to determine whether the cost of these products is justified in terms of the benefits provided. The iBRA study (implant-based Breast Reconstruction evaluAtion) is a UK multicentre audit which is designed to explore the practice and outcomes of implant-based reconstructions [54]. Data derived from this study will not only provide a large amount of prospective data but will help to inform the design of any future trials in this area. 


\section{References}

1. Foster C, Wright D, and Hill H, et al (2009) Psychosocial implications of living 5 years or more following a cancer diagnosis: a systematic review of the research evidence Eur J Cancer Care 18(3) 223-247 https://doi.org/10.1111/j.1365-2354.2008.01001.x

2. Eltahir Y, Werners LL, and Dreise MM, et al (2013) Quality-of-life outcomes between mastectomy alone and breast reconstruction: comparison of patient-reported BREAST-Q and other health-related quality-of-life measures Plast Reconstr Surg 132(2) 201e-209e https://doi.org/10.1097/PRS.0b013e31829586a7 PMID: 23897347

3. Jagsi R, Jiang J, and Momoh AO, et al (2014) Trends and variation in use of breast reconstruction in patients with breast cancer undergoing mastectomy in the United States J Clin Oncol 32(9) 919-926 https://doi.org/10.1200/JCO.2013.52.2284 PMID: 24550418 PMCID: 4876312

4. Jeevan R, Cromwell DA, and Browne JP, et al (2014) Findings of a national comparative audit of mastectomy and breast reconstruction surgery in England J Plast Reconstr Aesthet Surg 67(10) 1333-1344 https://doi.org/10.1016/j.bjps.2014.04.022 PMID: $\underline{24908545}$

5. Saint-Cyr M, Dauwe $P$, and Wong C, et al (2010) Use of the serratus anterior fascia flap for expander coverage in breast reconstruction Plast Reconstr Surg 125(4) 1057-1064 https://doi.org/10.1097/PRS.0b013e3181d17f61 PMID: 20335858

6. Isken T, Onyedi $\mathrm{M}$, and Izmirli $\mathrm{H}$, et al (2009) Abdominal fascial flaps for providing total implant coverage in one-stage breast reconstruction: an autologous solution Aesthetic Plast Surg 33(6) 853-858 https://doi.org/10.1007/s00266-009-9384-2 PMID: 19597865

7. Strock LL (2009) Two-stage expander implant reconstruction: recent experience Plast Reconstr Surg 124(5) 1429-1436 https:// doi.org/10.1097/PRS.0b013e31818b89da PMID: 19342993

8. Cordeiro PG and McCarthy CM (2006) A single surgeon's 12-year experience with tissue expander/implant breast reconstruction: part I. A prospective analysis of early complications Plast Reconstr Surg 118(4) 825-831 https://doi.org/10.1097/01. prs.0000232362.82402.e8 PMID: 16980842

9. Spear SL, Sher SR, and Al-Attar A, (2012) Focus on technique: supporting the soft-tissue envelope in breast reconstruction Plast Reconstr Surg 130(5) 89S-94S https://doi.org/10.1097/PRS.0b013e3182625852 PMID: 23096992

10. Mioton LM, Jordan SW, and Kim JY (2015) A prospective analysis of dynamic loss of breast projection in tissue expanderimplant reconstruction Arch Plast Surg 42(3) 309-315 https://doi.org/10.5999/aps.2015.42.3.309 PMID: 26015886 PMCID: 4439590

11. Scheflan M and Colwell AS (2014) Tissue reinforcement in implant-based breast reconstruction Plast Reconstr Surg Glob Open 2(8) e192 https://doi.org/10.1097/GOX.0000000000000140 PMID: 25426375 PMCID: 4236353

12. Colwell AS (2012) Direct-to-implant breast reconstruction Gland Surg 1(3) 139-141 PMID: 25083436 PMCID: 4115696

13. Breuing $\mathrm{KH}$ and Colwell AS (2007) Inferolateral AlloDerm hammock for implant coverage in breast reconstruction Ann Plast Surg 59(3) 250-255 https://doi.org/10.1097/SAP.0b013e31802f8426 PMID: 17721209

14. Bindingnavele V, Gaon M, and Ota KS, et al (2007) Use of acellular cadaveric dermis and tissue expansion in postmastectomy breast reconstruction J Plast Reconstr Aesthet Surg 60(11) 1214-1218 https://doi.org/10.1016/j.bjps.2007.03.015 PMID: 17459797

15. Badylak SF, Freytes DO, and Gilbert TW (2009) Extracellular matrix as a biological scaffold material: structure and function Acta Biomater 5(1) 1-13 https://doi.org/10.1016/j.actbio.2008.09.013

16. Debels $\mathrm{H}$, Hamdi M, and Abberton $\mathrm{K}$, et al (2015) Dermal matrices and bioengineered skin substitutes: a critical review of current options Plast Reconstr Surg Glob Open 3(1) e284 https://doi.org/10.1097/GOX.0000000000000219 PMID: 25674365 PMCID: 4323388 
17. Gubitosi A, Docimo G, and Parmeggiani D, et al (2014) Acellular bovine pericardium dermal matrix in immediate breast reconstruction after skin sparing mastectomy Int J Surg 12(1) S205-S208 https://doi.org/10.1016/j.ijsu.2014.05.007 PMID: 24859403

18. Cabalag MS, Rostek M, and Miller GS, et al (2016) Alloplastic adjuncts in breast reconstruction Gland Surg 5(2) 158-173 PMID: $\underline{27047784}$ PMCID: 4 7791350

19. Dieterich M, Paepke S, and Zwiefel K, et al (2013) Implant-based breast reconstruction using a titanium-coated polypropylene mesh (TiLOOP Bra): a multicenter study of 231 cases Plast Reconstr Surg 132(1) 8e-19e https://doi.org/10.1097/ PRS.0b013e318290f8a0 PMID: 23806958

20. Fine NA, Lehfeldt M, and Gross JE, et al (2015) SERI surgical scaffold, prospective clinical trial of a silk-derived biological scaffold in two-stage breast reconstruction: 1-year data Plast Reconstr Surg 135(2) 339-351 https://doi.org/10.1097/ PRS.0000000000000987

21. Becker $\mathrm{H}$ and Lind JG The use of synthetic mesh in reconstructive, revision, and cosmetic breast surgery Aesthetic Plast Surg 37(5) 914-921 PMID: 23860816 PMCID: $\underline{3778996}$

22. Tessler O, Reish RG, and Maman DY, et al (2014) Beyond biologics: absorbable mesh as a low-cost, low-complication sling for implant-based breast reconstruction Plast Reconstr Surg 133(2) 90e-9e https://doi.org/10.1097/01.prs.0000437253.55457.63 PMID: 24469217

23. Potter S, Browning D, and Savović J, et al (2015) Systematic review and critical appraisal of the impact of acellular dermal matrix use on the outcomes of implant-based breast reconstruction Br J Surg 102(9) 1010-1025 https://doi.org/10.1002/bjs.9804 PMID: $\underline{26109277}$

24. Ho G, Nguyen TJ, and Shahabi A, et al (2012) A systematic review and meta-analysis of complications associated with acellular dermal matrix-assisted breast reconstruction Ann Plast Surg 68(4) 346-356 https://doi.org/10.1097/SAP.0b013e31823f3cd9 PMID: 22421476

25. JoAnna Nguyen T, Carey JN, and Wong AK (2011) Use of human acellular dermal matrix in implant- based breast reconstruction: evaluating the evidence J Plast Reconstr Aesthet Surg 64(12) 1553-1561 https://doi.org/10.1016/j.bjps.2011.02.001 PMID: $\underline{21388901}$

26. Lee KT and Mun GH (2016) Updated evidence of acellular dermal matrix use for implant-based breast reconstruction: a meta-analysis Ann Surg Oncol 23(2) 600-610 https://doi.org/10.1245/s10434-015-4873-9

27. Sbitany $\mathrm{H}$ and Serletti JM (2011) Acellular dermis-assisted prosthetic breast reconstruction: a systematic and critical review of efficacy and associated morbidity Plast Reconstr Surg 128(6) 1162-1169 https://doi.org/10.1097/PRS.0b013e318230c29e PMID: $\underline{22094735}$

28. Ibrahim AM, Koolen PG, and Ganor O, et al (2015) Does acellular dermal matrix really improve aesthetic outcome in tissue expander/implant-based breast reconstruction? Aesthetic Plast Surg 39(3) 359-368 https://doi.org/10.1007/s00266-015-0484-x PMID: 25894022

29. Forsberg CG, Kelly DA, and Wood BC, et al (2014) Aesthetic outcomes of acellular dermal matrix in tissue expander/implantbased breast reconstruction Ann Plast Surg 72(6) S116-S120 https://doi.org/10.1097/SAP.00000000000000098 PMID: 24374398

30. Vardanian AJ, Clayton JL, and Roostaeian J, et al (2011) Comparison of implant-based immediate breast reconstruction with and without acellular dermal matrix Plast Reconstr Surg 128(5) 403e-410e https://doi.org/10.1097/PRS.0b013e31822b6637 PMID: $\underline{22030500}$

31. Nguyen KT, Mioton LM, and Smetona JT, et al (2012) Esthetic outcomes of adm-assisted expander-implant breast reconstruction Eplasty 12 e58 
32. Clough KB, O'Donoghue JM, and Fitoussi AD, et al (2001) Prospective evaluation of late cosmetic results following breast reconstruction: I. Implant reconstruction Plast Reconstr Surg 107(7) 1702-1709 https://doi.org/10.1097/00006534-200106000-00010 PMID: 11391188

33. McCarthy CM, Lee CN, and Halvorson EG, et al (2012) The use of acellular dermal matrices in two-stage expander/implant reconstruction: a multicenter, blinded, randomized controlled trial Plast Reconstr Surg 130(5) 57S-66S https://doi.org/10.1097/ PRS.0b013e31825f05b4 PMID: 23096987 PMCID: 4100590

34. Hanna KR, DeGeorge BR Jr, and Mericli AF et al (2013) Comparison study of two types of expander-based breast reconstruction: acellular dermal matrix-assisted versus total submuscular placement Ann Plast Surg 70(1) 10-5 https://doi.org/10.1097/ SAP.0b013e31822f6765

35. Seth AK, Hirsch EM, and Fine NA, et al (2012) Utility of acellular dermis-assisted breast reconstruction in the setting of radiation: a comparative analysis Plast Reconstr Surg 130(4) 750-758 https://doi.org/10.1097/PRS.0b013e318262f009 PMID: 23018687

36. Basu CB and Jeffers L (2012) The role of acellular dermal matrices in capsular contracture: a review of the evidence Plast Reconstr Surg 130(5) 118S-124S https://doi.org/10.1097/PRS.0b013e318262df58 PMID: 23096960

37. Salzberg CA, Ashikari AY, and Berry C, et al (2016) A cellular dermal matrix-assisted direct-to-implant breast reconstruction and capsular contracture: a 13-year experience Plast Reconstr Surg 138(2) 329-337 https://doi.org/10.1097/PRS.0000000000002331 PMID: 27064232

38. Krishnan NM, Chatterjee A, and Rosenkranz KM, et al (2014) The cost effectiveness of acellular dermal matrix in expanderimplant immediate breast reconstruction J Plast Reconstr Aesthet Surg 67(4) 468-476 https://doi.org/10.1016/j.bjps.2013.12.035 PMID: 24508194

39. de Blacam C, Momoh AO, and Colakoglu S, et al (2012) Cost analysis of implant-based breast reconstruction with acellular dermal matrix Ann Plast Surg 69(5) 516-520 https://doi.org/10.1097/SAP.0b013e318217fb21

40. Macadam SA and Lennox PA (2012) Acellular dermal matrices: use in reconstructive and aesthetic breast surgery Can J Plast Surg 20(2) 75-89 https://doi.org/10.1177/229255031202000201 PMCID: 3383551

41. Johnson RK, Wright CK, and Gandhi A, et al (2013) Cost minimisation analysis of using acellular dermal matrix (StratticeTM) for breast reconstruction compared with standard techniques Eur J Surg Oncol 39(3) 242-247 https://doi.org/10.1016/j. ejso.2012.12.002

42. Kilchenmann AJ, Lardi AM, and Ho-Asjoe M, et al (2014) An evaluation of resource utilisation of single stage porcine acellular dermal matrix assisted breast reconstruction: a comparative study Breast 23(6) 876-882 https://doi.org/10.1016/j. breast.2014.09.008 PMID: $\underline{25311295}$

43. Bank J, Phillips NA, and Park JE, et al (2013) Economic analysis and review of the literature on implant-based breast reconstruction with and without the use of the acellular dermal matrix Aesthetic Plast Surg 37(6) 1194-1201 https://doi.org/10.1007/ s00266-013-0213-2 PMID: $\underline{24091489}$

44. Dieterich M, Angres J, and Stubert J, et al (2015) Patient-reported outcomes in implant-based breast reconstruction alone or in combination with a titanium-coated polypropylene mesh - a detailed analysis of the BREAST-Q and overview of the literature Geburtshilfe und Frauenheilkunde 75(7) 692-701 https://doi.org/10.1055/s-0035-1546218 PMID: 26257406 PMCID: $\underline{4520995}$

45. Gschwantler-Kaulich D, Schrenk P, and Bjelic-Radisic V et al (2016) Mesh versus acellular dermal matrix in immediate implantbased breast reconstruction - a prospective randomized trial Eur J Surg Oncol 42(5) 665-671 https://doi.org/10.1016/j. ejso.2016.02.007 PMID: 26947961 
46. Lee KT and Mun GH (2016) Updated evidence of acellular dermal matrix use for implant-based breast reconstruction: a metaanalysis Ann Surg Oncol 23(2) 600-610 https://doi.org/10.1245/s10434-015-4873-9

47. Sbitany $\mathrm{H}$ and Serletti JM (2011) Acellular dermis-assisted prosthetic breast reconstruction: a systematic and critical review of efficacy and associated morbidity Plast Reconstr Surg 128(6) 1162-1169 https://doi.org/10.1097/PRS.0b013e318230c29e PMID: $\underline{22094735}$

48. Newman MI, Swartz KA, and Samson MC, et al (2011) The true incidence of near-term postoperative complications in prosthetic breast reconstruction utilizing human acellular dermal matrices: a meta-analysis Aesthetic Plast Surg 35(1) 100-106 https://doi. org/10.1007/s00266-010-9631-6

49. Kim JY, Davila AA, and Persing S, et al (2012) A meta-analysis of human acellular dermis and submuscular tissue expander breast reconstruction Plast Reconstr Surg 129(1) 28-41 https://doi.org/10.1097/PRS.0b013e3182361fd6

50. Ho G, Nguyen TJ, and Shahabi A, et al (2012) A systematic review and meta-analysis of complications associated with acellular dermal matrix-assisted breast reconstruction Ann Plast Surg 68(4) 346-356 https://doi.org/10.1097/SAP.0b013e31823f3cd9 PMID: 22421476

51. Potter S, Holcombe C, and Ward JA, et al (2015) Development of a core outcome set for research and audit studies in reconstructive breast surgery Br J Surg 102(11) 1360-1371 https://doi.org/10.1002/bjs.9883 PMID: 26179938 PMCID: 5034747

52. Maass SW, Bagher S, and Hofer SO, et al (2015) Systematic review: aesthetic assessment of breast reconstruction outcomes by healthcare professionals Ann Surg Oncol 22(13) 4305-4316 https://doi.org/10.1245/s10434-015-4434-2 PMID: 25691279

53. Potter S, Browning D, and Savović J, et al (2015) Systematic review and critical appraisal of the impact of acellular dermal matrix use on the outcomes of implant-based breast reconstruction BrJ Surg 102(9) 1010-1025 https://doi.org/10.1002/bjs.9804 PMID: $\underline{26109277}$

54. Potter S, Conroy EJ, and Williamson PR, et al (2016) The iBRA (implant breast reconstruction evaluation) study: protocol for a prospective multi-centre cohort study to inform the feasibility, design and conduct of a pragmatic randomised clinical trial comparing new techniques of implant-based breast reconstruction Pilot Feasibility Stud 241 https://doi.org/10.1186/s40814-0160085-8 